\title{
Two-step procedure for multi-criteria choice of generating-capacity structure in remote areas
}

\author{
Aleksandr Nefedov*, and Vladislav Shakirov, Bratsk State University, Bratsk, Russia
}

\begin{abstract}
The paper dwells upon the problem of multi-criteria choice of ways to develop generating capacities to supply power to remote consumers. We herein propose a two-step multi-criteria analysis method: choosing promising power-generation technology first, and then specifying the generating-capacity structure. The paper describes the structure of the proposed multi-criteria methods: the interval TOPSIS method for Step 1; for Step 2, an upgraded analytic hierarchy process based on identifying the structure of the decision maker's preferences. We demonstrate the use of this method with evidence from the Penzhinsky District, Kamchatka Krai. Thermal power plants, hydroelectric power plants, diesel power plants, as well as solar and wind power are analyzed as power sources. Step 1 includes: analyzing the potential power-supply loads in a specific area; formulating alternative power-generation technology; formulating goals and criteria; criterion-based evaluation of alternative options using objective and subjective models; multi-criteria evaluation of alternatives; analyzing the sensitivity of results and the selection of promising technology. Step 2 includes: formulating goals and criteria on the basis of the selected power-generation technologies; formulating the available alternatives; criterion-based evaluation of alternatives; multi-criteria evaluation and final decision-making.
\end{abstract}

\section{Introduction}

Supplying power to remote consumers in North-Eastern Russia is still a problem. Remote areas have scattered power sources and an underdeveloped infrastructure in general [1]. When analyzing the development of such areas, one has to assess the feasibility of establishing local power grids using local fuels and renewable energy [2, 3, 4]. Today, there exist multiple different methods for the structural optimization of generating capacities; these methods are based on analyzing techno-economic factors alone [5, 6]. However, comprehensive evaluation reveals various impacts that the available alternatives might bring, which is why multi-criteria analysis of power infrastructure and its development in such areas is imperative.

\footnotetext{
*Corresponding author: Domino1991@rambler.ru
} 


\section{Two-step procedures for selecting the generating-capacity structure in remote areas}

To solve the problem, we herein propose a two-step procedure for multi-criteria analysis of the structural development of generating capacities; Fig. 1 presents the main points of the procedure.

Step 1 Choosing a promising technology
1.1 Analyzing the potential power-supply loads in a specific area;
1.2 Formulating the available power-supply alternatives;
1.3 Formulating the goals and criteria;
1.4 Criterion-based evaluation of alternatives using objective and subjective models;
1.5 Multi-criteria evaluation of alternatives using the interval TOPSIS method;
1.6 Analyzing the sensitivity of results and choosing a promising technology
Step 2 Optimizing the generating-capacity structure
1.1 Formulating the goals and criteria on the basis of the selected power-generation technology;
1.2 Formulating the alternative generating-capacity structure;
1.3 Criterion-based evaluation of the alternatives;
1.4 Multi-criteria evaluation of the alternatives;
1.5. Selecting the final generating-capacity structure.

Fig. 1. Two-step generating-capacity selection procedure: the structure

Step 1 (Fig. 1) included the collection of the necessary data on a power-supply location and its primary power consumers (as planned); multi-criteria assessment of the primary power-generation technologies that can ensure reliable power supply to such consumers. Step1 was first targeted at selecting the best power-generation technology for future use. Step 2 included detailed multi-criteria evaluation of the selected technologies as well as finalizing the generating-capacity structure.

\section{Multi-criteria evaluation methods for choosing promising power-generation technologies}

For Step-1 multi-criteria evaluation (Fig. 1), we chose such well-known method as the interval TOPSIS method. For Step 2, we chose a modified Analytic Hierarchy Process (AHP).

\subsection{TOPSIS}

Dealing with uncertainty in the input data and the decision-maker's preferences, we decided to use the interval TOPSIS method.

The method includes the following steps [7]:

- formulating a set of alternatives and criteria;

- vector normalization of data by intervals and weights;

- finding the best and the worst inter-alternative borders;

- finding each alternative's distance to the best and the worst border;

- finding the best alternative. 
The method is essentially about recognizing such object as the best alternative that minimizes the distance from the best alternative (by the aggregate of all criteria) and maximizes the distance from the worst alternative $[8,9,10]$.

To that end, calculate the total distance $\mathrm{D}^{+}$from each alternative to the best solution; and the total distance $\mathrm{D}_{\mathrm{j}}^{-}$to the worst solution:

$$
\begin{aligned}
& D_{j}^{+}=\sqrt{\sum_{i=1}^{I}\left(v_{i j}^{L}-A_{i}^{+}\right)^{2}+\sum_{i=1}^{J}\left(v_{i j}^{U}-A_{i}^{+}\right)^{2}} \\
& D_{j}^{-}=\sqrt{\sum_{i=1}^{I}\left(v_{i j}^{U}-A_{i}^{-}\right)^{2}+\sum_{i=1}^{J}\left(v_{i j}^{L}-A_{i}^{-}\right)^{2}}
\end{aligned}
$$

Where $v_{i j}^{L}, v_{i j}^{U}$ are the evaluation criteria in the upper and the lower boundaries of the interval evaluation that include the normalized alternative evaluations and criterion weights; $A_{i}^{+}, A_{i}^{-}$are the best- and the worst-alternative levels; $I$ is the set of indices of the parameters to maximize; $J$ is the set of indices of the parameters to minimize.

The assessment criterion $\mathrm{C}^{*}{ }_{\mathrm{i}}$ is calculated as:

$$
C_{j}^{*}=\frac{D_{j}^{-}}{D_{j}^{+}+D_{j}^{-}} \quad(j=1,2, \ldots, n) \quad\left(0 \leq C_{j}^{*} \leq 1\right)
$$

Its advantages are as follows: option to configure interval estimates; minimum number of queries to the decision maker; quantitative multi-criteria evaluation of alternatives; using two measures for evaluation of alternatives; simple and easy to use for the decision maker.

\subsection{Modified Analytic Hierarchy Process}

The original AHP uses pairwise-comparison matrices based on a pairwise-comparison scale so as to evaluate the decision-maker's preferences, see Table 1.

Table 1. Pairwise-comparison scale

\begin{tabular}{|c|c|}
\hline Relative importance & Score \\
\hline Equal importance & 1 \\
\hline Moderate importance & 3 \\
\hline Strong importance & 5 \\
\hline Demonstrated importance & 7 \\
\hline Extreme importance & 9 \\
\hline
\end{tabular}

Solving a problem with multiple alternatives makes this step quite difficult.

This is why we decided to use an author-modified Analytic Hierarchy Process (AHP) for Step 2, see Figure 1. The structure and upgrades of this method are presented in papers $[11,12]$. Upgrades are essentially about identifying the decision-maker's preferences while taking into account the uncertainty caused by the small number of queries to the decision-maker.

To that end, we propose creating a dialog where the decision-maker could help find Level 3 Moderate Importance as a function of criterion-based evaluations, see Fig. 2a. The Figure shows relative-importance evaluations as a function the alterations in the estimates $\Delta x$ within the estimate range from $x_{k}{ }^{0}$ to $x_{k}{ }^{n}$ by the criterion. The dialog is then used to generate the decision-maker's criterion-based preference structure for the pairs of alternatives, see Fig. 2b. The Figure shows the areas that, hitting which the alternatives to compare are scored accordingly, see Table 1. 


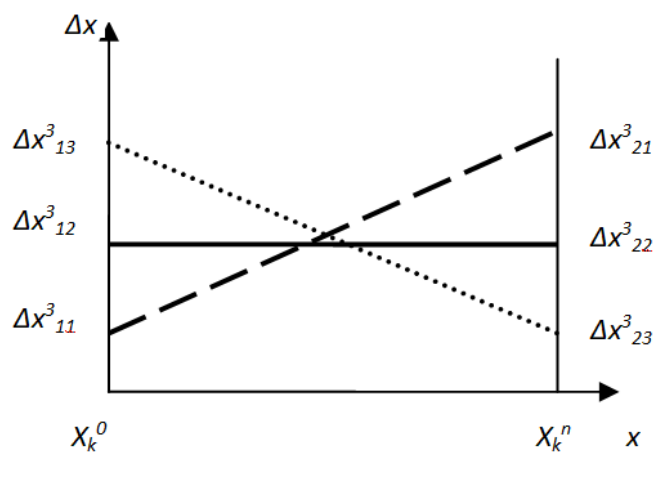

a

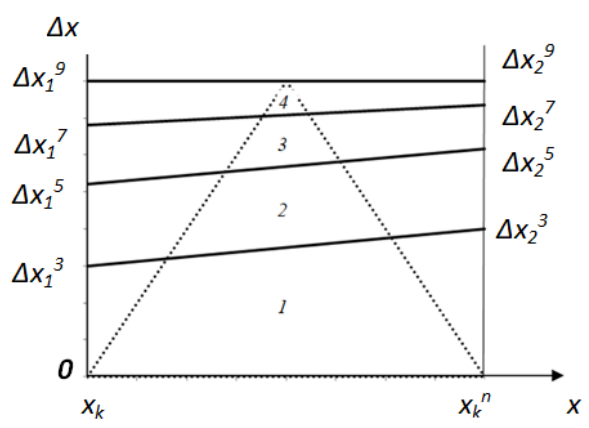

b

Fig. 2. Decision-maker's perception of Level 3 Moderate Importance and probable structure of the decision-maker's preferences with respect to the paired alternatives

This enables automated filling of the pairwise-comparison matrices by interpolation. Further steps follow the original AHP.

For practical use, the above model for generating-capacity selection is proposed for tests with evidence from a remote consumer located in the village of Kamenskoye, Kamchatka Krai.

\section{Choosing the generating-capacity structure for the Penzhisnky District, Kamchatka Krai}

\subsection{Selecting the best power-generation technology for future use}

4.1.1 Analyzing the potential power-supply loads in the area; formulating the power-supply options, goals, and criteria

For Step 1, one must select the best ways to supply power. To that end, potential powersupply loads specific to the area are analyzed using data from territorial-planning and construction-site charts, as well as mineral-deposit maps [13, 14].

In our case, power-supply load amounted to $100 \mathrm{MW}$ as calculated using data on similar enterprises located in the same region. The following potential power sources were analyzed: thermal power plants (TPP), hydroelectric power plants (HPP), diesel power plants (DPP), solar farms (SF) and wind farms (WF).

Step1 is targeted at selecting the best power-generation technology for future use. Our analysis employed the following criteria: net present value (NPV); required area; environmental impact (hazardous atmospheric emissions, waste generation, biological impact on the ecosystem); social factors (popular attitude to any specific technology, health damage, occupational mortality risks); technological efficiency (maneuverability of, and sufficiency of resources for, the plant). When evaluating the technologies herein proposed for social and biological factors, we used subjective models and expert opinions. 


\subsubsection{Analysis of land areas required for various power-generation technologies}

When evaluating the possible construction of an HPP, we estimated the hydrological potential of the Penzhina River and its tributaries [15]. The Belaya River was selected as the construction site.

Our hydroelectric power calculations were done in the following steps:

1. Find the reservoir-surface area as a function of the reservoir water level.

2. Find the minimum required "dead" reservoir volume.

3. Calculated the minimum necessary water flow to the turbines during low-water years for each alternative normal head-water level of the dam.

4. Calculate the minimum annual HPP productivity rates taking into account the redistribution of runoffs over the year for each alternative normal head-water level of the dam.

Fig. 3a presents the calculated required land areas as a function of the plant capacity.

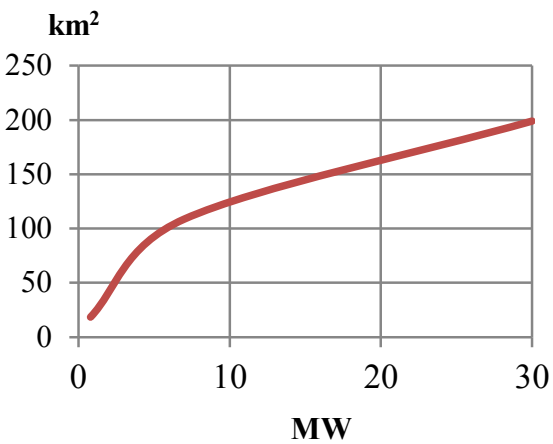

a

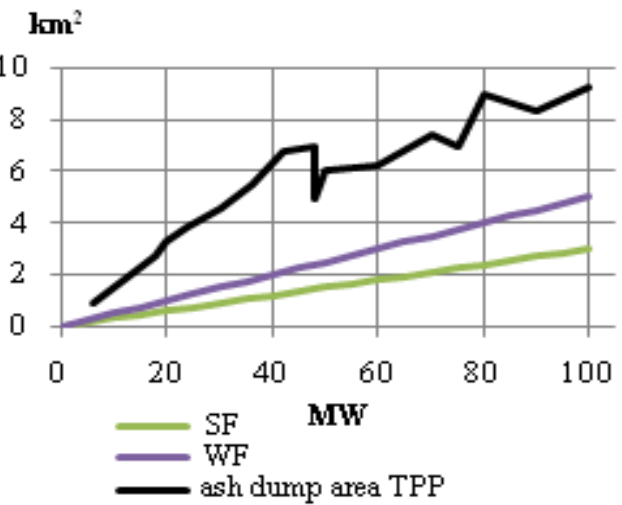

b

Fig. 3. Flooding area HPP and land area required for TPP, WF, SF as a function of plant capacity

The area required for WF and SF was calculated on the basis of specific land-intensity rates: 0.001 to $0.006 \mathrm{ha} / \mathrm{kW}$ for solar farms; 0.01 ha for wind farms [16]. TPP ash-pond areas are within $0.07 \mathrm{ha} / \mathrm{TOE}$ of fuel consumed. Figure $3 \mathrm{~b}$ shows the land areas required for 25 years of TPP/WF/SF operation as a function of capacity.

\subsubsection{Sufficiency of energy resources}

Our evaluation of resource sufficiency was based on the wind-speed re-occurrence rates as measured by metrological stations (readings available at rp5.ru); we only took into account such wind speeds that enable consistent wind-farm operation. For SF analysis, we took into account the sunshine periods throughout the year. Table 2 presents the overall evaluations.

Table 2. Sufficiency of solar and wind-power resources

\begin{tabular}{|c|c|c|c|c|c|}
\hline \multicolumn{2}{|c|}{ Solar power potential } & \multicolumn{3}{c|}{ Wind-power potential } \\
\hline $\begin{array}{c}\text { Period under } \\
\text { consideration, } \mathrm{h}\end{array}$ & $\begin{array}{c}\text { Duration of } \\
\text { sunshine per annum }\end{array}$ & Rating & $\begin{array}{c}\text { Total } \\
\text { measurements }\end{array}$ & $\begin{array}{c}\text { Wind exceeding } \\
3 \mathrm{~m} / \mathrm{s}\end{array}$ & Rating \\
\hline 8,760 & 4,488 & 0.51 & 22,795 & 9,993 & 0.43 \\
\hline
\end{tabular}




\subsubsection{Multicriteria analysis of technologies by the TOPSIS method.}

When carrying out criterion-based evaluation of alternatives by means of objective and subjective models, the values shown in Table 3 were obtained for further multi-criteria analysis.

Table 3. Criterion-based comparison of alternatives per $1 \mathrm{~kW}$ of installed capacity

\begin{tabular}{|c|c|c|c|c|c|}
\hline $\mathrm{X}$ & $\begin{array}{c}\mathrm{K}_{1} \\
\text { NPV, RUB }\end{array}$ & $\begin{array}{c}\mathrm{K}_{2} \\
\text { (Land area } \\
\text { required, } \mathrm{m}^{2} \text { ) }\end{array}$ & $\begin{array}{c}\mathrm{K}_{3} \\
\text { (Environmental } \\
\text { impact) }\end{array}$ & $\begin{array}{c}\mathrm{K}_{4} \\
\text { (Social } \\
\text { factors) }\end{array}$ & $\begin{array}{c}\mathrm{K}_{5} \\
\text { (Technological } \\
\text { efficiency) }\end{array}$ \\
\hline TPP & 98,529 to 121,279 & 92 to 165 & 1 & 3 & 4 \\
\hline WF & 2,000 to 47,500 & 50 to 100 & 4 & 4 & 2 \\
\hline HPP & 465,000 to 562,500 & 6,633 to 6,633 & 3 & 4 & 5 \\
\hline SF & 28,725 to 96,975 & 10 to 60 & 5 & 5 & 2 \\
\hline DPP & $-799,103$ to $(-799,643)$ & 0 & 2 & 2 & 5 \\
\hline
\end{tabular}

TOPSIS interval method returned the following results, see Table 4.

Table 4. Final evaluation of alternatives by means of the multi-criteria TOPSIS method

\begin{tabular}{|c|c|c|c|c|}
\hline HPP & TPP & SF & WF & DPP \\
\hline 0.737862 & 0.643679 & 0.634865 & 0.606192 & 0.341608 \\
\hline
\end{tabular}

According to Table 4, technologies were ranked as follows: HPP $>$ TPP $>$ SF. Therefore, these three alternatives were assumed for further analysis. WF and DPP were thus excluded.

\subsection{Specifying the generating-capacity structure for the most precise description of the impacts of selected power-generation technologies}

Step 2 included a more detailed goal and criterion hierarchy based on the specific conjunction of the selected technology types. For this case, the following subcriteria were proposed for HPP/TPP/SF technologies, see Fig. 4.

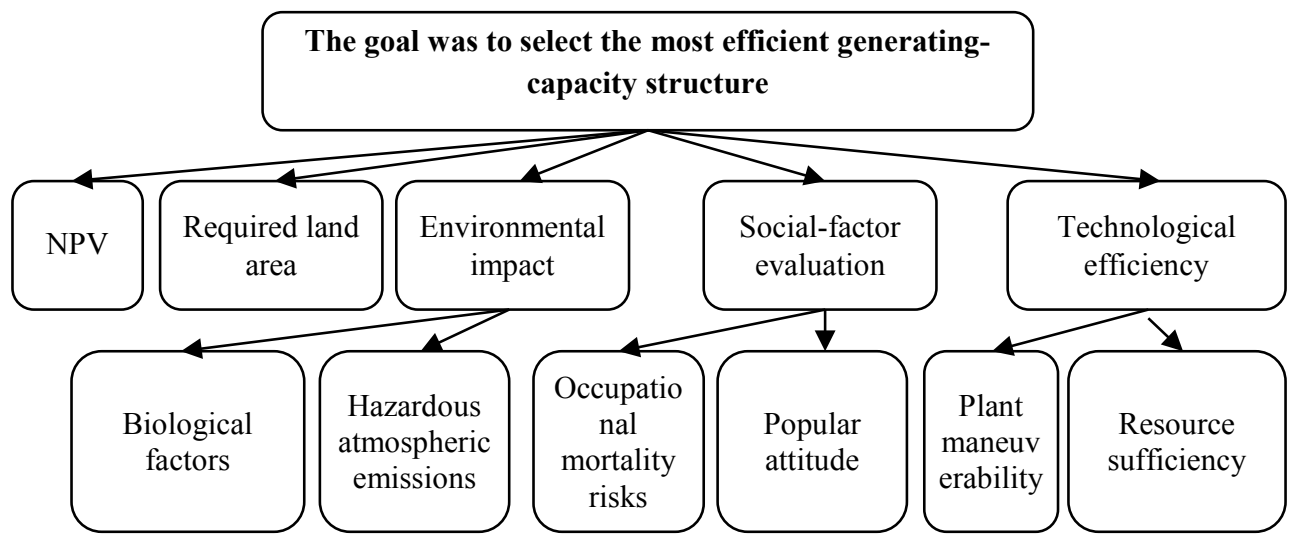

Fig. 4. Specified hierarchy of goals and criteria for the selected technologies 
Given these criteria, the alternatives were evaluated as follows, see Table 5.

Table 5. Criterion-based evaluation of the alternatives

\begin{tabular}{|c|c|c|c|c|}
\hline & NPV, RUB & Land area required, $\mathrm{m}^{2}$ & Emissions, t/year & Biological impact \\
\hline \multicolumn{5}{|c|}{ Per $1 \mathrm{~kW}$ of installed capacity } \\
\hline TPP & 109,904 & 128.5 & 9,737 & 4 \\
\hline HPP & 513,750 & 6,633 & 0 & 9 \\
\hline SF & 62,850 & 35 & 0 & 2 \\
\hline & $\begin{array}{l}\text { Occupational } \\
\text { mortality risks }\end{array}$ & $\begin{array}{l}\text { Popular attitude (10-point } \\
\text { scoring scale) }\end{array}$ & $\begin{array}{l}\text { Reliability (resource } \\
\text { sufficiency) }\end{array}$ & Maneuverability \\
\hline \multicolumn{5}{|c|}{ Per $1 \mathrm{~kW}$ of installed capacity } \\
\hline TPP & 7 & 4 & 0.9 & 3 \\
\hline HPP & 4 & 3 & 1 & 10 \\
\hline $\mathrm{SF}$ & 2 & 9 & 0.51 & 1 \\
\hline
\end{tabular}

We further carried out multi-criteria evaluation by the upgraded analytic hiearchy process. We formulated the set of alternatives given the specific conjunction of various power-generation technologies. Given that there were numerous alternatives, they were preselected. As a result, the best solution was found in a limited set of alternatives, see Table 6 .

Table 6. Final set of alternatives for finding the best solution

\begin{tabular}{|c|c|c|c|c|c|c|c|c|c|c|c|}
\hline & \multirow{3}{*}{$\mathrm{K}_{1}$} & \multirow{3}{*}{$\mathrm{K}_{2}$} & \multicolumn{2}{|c|}{$\mathrm{K}_{3}$} & \multicolumn{2}{|c|}{$\mathrm{K}_{4}$} & \multicolumn{2}{|c|}{$\mathrm{K}_{5}$} & \multirow{3}{*}{ RANK } \\
\hline & & & & & \multirow[t]{2}{*}{$\mathrm{K}_{31}$} & \multirow[t]{2}{*}{$\mathrm{K}_{32}$} & \multirow[t]{2}{*}{$\mathrm{K}_{41}$} & \multirow[t]{2}{*}{$\mathrm{K}_{42}$} & \multirow[t]{2}{*}{$\mathrm{K}_{51}$} & \multirow[t]{2}{*}{$\mathrm{K}_{52}$} & \\
\hline TPP & HPP & SF & & & & & & & & & \\
\hline \multicolumn{3}{|c|}{ MW } & & & & & & & & & \\
\hline 70 & 30 & 0 & 8.43 & 652.055 & 5.5 & $6,815.9$ & 6.1 & 3.3 & 5.1 & 0.93 & 0.146597 \\
\hline 65 & 30 & 5 & 8.20 & 652.52 & 5.4 & $6,329.05$ & 5.85 & 3.4 & 5 & 0.9105 & 0.114781 \\
\hline 60 & 30 & 10 & 7.96 & 652.99 & 5.3 & $5,842.2$ & 5.6 & 3.5 & 4.9 & 0.891 & 0.097724 \\
\hline 55 & 30 & 15 & 7.72 & 653.45 & 5.2 & $5,355.35$ & 5.35 & 3.6 & 4.8 & 0.8715 & 0.084648 \\
\hline 80 & 20 & 0 & 9.28 & 651.52 & 5 & \begin{tabular}{|l|}
$7,789.6$ \\
\end{tabular} & 6.4 & 3.2 & 4.4 & 0.92 & 0.095357 \\
\hline 75 & 20 & 5 & 9.05 & 651.98 & 4.9 & $7,302.75$ & 6.15 & 3.3 & 4.3 & 0.9005 & 0.074165 \\
\hline 70 & 15 & 20 & 9.32 & 685.64 & 4.55 & $6,815.9$ & 5.9 & 3.7 & 3.8 & 0.882 & 0.099734 \\
\hline 90 & 10 & 0 & 10.13 & 650.98 & 4.5 & \begin{tabular}{|l|}
$8,763.3$ \\
\end{tabular} & 6.7 & 3.1 & 3.7 & 0.91 & 0.09493 \\
\hline 80 & 10 & 10 & 9.66 & 651.92 & 4.3 & $7,789.6$ & 6.2 & 3.3 & 3.5 & 0.871 & 0.064077 \\
\hline 100 & 0 & 0 & 10.9904 & 650.45 & 4 & 9,737 & 7 & 3 & 3 & 0.9 & 0.127987 \\
\hline
\end{tabular}

The analysis and ranking of alternatives by modified analytic hierarchy process returned the following final generating-capacity ranks:

Rank \#1: 70-MW TPP, 30-MW HPP, rank $=0.146$

Rank \#2: 100-MW TPP, rank $=0.127$

Rank \#3: 65-MW TPP, 30-MW HPP, 5-MW SF, rank = 0.114

Analysis of results shows that when taking into account environmental and social criteria, an HPP is a better power source than a TPP; however, its capacity is limited by the economically justified land-area requirement. When taking into account the technological efficiency, which is crucial for the decision maker in this case, solar farms are worse than HPP or TPP. In such cases, the best option is the alternative of HPP and TPP. 


\section{Implications}

Thus, this paper presents the following:

- A two-step methodology for multi-criteria analysis of generating-capacity structure for remote areas;

- Multi-criteria analysis methods for both steps, using which minimizes the number of queries to the decision-maker while allowing to take into account the input uncertainty;

- A modified analytic hierarchy procedure to minimize the number of Step-2 queries to the decision-maker;

- Goal and criteria hierarchies, baseline models for the evaluation of alternatives;

- A test of the proposed method in the case of selecting a generating-capacity structure for the Penzhinsky District, Kamchatka Krai.

\section{References}

1. Role of Low-Power Plants in the Areas of Decentralized Power Supply to Consumers Residing in Eastern Russia (Rol elektrostantsy maloy moshchnosti v zonakh detsentralizovannogo energosnabzheniya potrebiteley na vostoke Rossii) // Open Workshop. Economic Problems of the Energy Complex (Ekonomicheskiye problemy energeticheskogo kompleksa), p. 28-43 (2011).

2. V.A. Savelyev, L.Yu. Chudinova. Hydroelectric Power Development Prospects in Eastern Russia (Perspektivy razvitiya gidroenergetiki vostochnykh rayonov Rossii) // Power: Technology, Economy, Ecology (Energiya: tekhnika, ekonomika, ekologiya). Issue 7, p. 2-9 (2009).

3. N.I. Voropay, B.G. Saneyev, I.Yu. Ivanova. Comparative Efficiency of Using LowPower Nuclear Plants in Local Power Systems in Eastern Russia (Sravnitelnaya effektivnost ispolzovaniya atomnykh stantsy maloy moshchnosti $\mathrm{v}$ lokalnykh energosistemakh na vostoke Rossii) // Low-Power Nuclear Plants: a New Ambition in Power Engineering (Atomnye stantsii maloy moshchnosti: novoye napravleniye razvitiya energetiki: Vol.2/ed. by the RAS Academician A.A. Sarkisov. - Moscow: Akadem-Print, 387 p. (2015).

4. I.Yu. Ivanova, T.F. Tuguzova. Systematic Efficiency Evaluation of Multiple Alternatives for Power and Fuel Supply to Decentralized Consumers: Methodical Approaches and Research Results (Sistemnaya otsenka effektivnosti variantov energo-, toplivosnabzheniya detsentralizovannykh potrebiteley: metodicheskiye podkhody i rezultaty issledovany) // 7th Melentyev Forum. Forecasting the Development of Power Engineering in Russia and Worldwide: Approaches, Problems, Solutions. (Sedmye Melentyevskiye chteniya. Prognozirovaniye razvitiya mirovoy i rossyskoy energetiki: podkhody, problemy, resheniya.) Book of Proceedings. Moscow, p. 196-205 (2013).

5. D.S. Shchavelev, Yu.B.Guk, M.P.Fyodorov etc. Fundamentals of Optimal DecisionMaking in Power-Engineering and Water-Management Systems (Osnovy vybora optimalnykh resheny $\mathrm{v}$ cistemakh energetiki i vodnogo khozyaystva); Leningrad: Kalinin Leningrad Polytechnic Institute, 83 p. (1977).

6. Power Engineering Systems and Grids: Development Models (Elektroenergeticheskiye systemy i seti: modeli razvitiya): textbook for universities / S.S. Ananicheva, P.Ye. Mezhentsev, A.L. Myzin; endorsed by P.I. Bartolomey. - Moscow: Uraiy; Yekaterinburg: Ural University Publisher, 148 p. (2018).

7. G.R. Jahanshahloo, F. Hosseinzadeh Lofli, M. Izadikhah. An algorithmic method to extend TOPSIS for decision-making problems with interval data // Applied Mathematics and Compulation 175, 1375-1384 (2006). 
8. L.B. Parfenova, A.A. Pugachev, A. Podvezko. Using Multi-Criteria Methods for the Comparative Evaluation of the Regional Tax Potential (Primeneniye mnogokriterialnykh metodov dlya sravnitelnoy otsenki nalogovogo potentsiala regionov) // Social and Humanitarian Knowledge (Sotsialnye i gumanitarnye znaniya). Vol. 3, Issue 1, p. 24-34 (2017).

9. C.L. Hwang, K. Yoon. Multiple Attribute Decision Making Methods and Applications. Berlin: Springer-Verlag, 259 p. (1981).

10. A. Podviezko, V. Podvezko. Absolute and Relative Evaluation of Socio-Economic Objects Based on Multiple Criteria Decision Making Methods // Inzinerine Ekonomika-Engineering Economics. № 25 (5), p. $522-529$ (2014).

11. A.S .Nefedov. Solving the Problem of Choosing a Power Source by Analytic Hierarchy Process (Resheniye zadachi vybora istochnika energosnabzheniya metodom analiza iyerarkhy) // State-of-the-Art and Development Prospects in Power and Heating Technologies (10th Benardos Forum) Proceedings of the International Scientific and Technical Conference dedicated to the 175th Anniversary of N.N. Benardos (Sostoyaniye i perspektivy razvitiya elektro- i teplotekhnologii (XIX Benardosovchskiye chteniya) Materialy Mezhdunarodnoy nauchno-tekhnicheskoy konferentsii, posvyashchennoy 175-letiyu so dnya rozhdeniya N.N. Benardosa), P. 5759 (2017).

12. A.S. Nefyodov, V.A. Shakirov. Modifying the Analytic Hierarchy Process to Reduce the Number of Queries to the Decision-Maker (Modifikatsiya metoda analiza iyerarkhy dlya snizheniya chisla zaprosov $\mathrm{k}$ litsu, prinimayushchemu resheniya) // Proceedings of Bratsk State University. Series: Natural and Engineering Science. Issue 2, p. 9-17 (2017).

13. http://old.kamgov.ru/index.php?cont $=$ oiv_din $\&$ mcont $=4165 \&$ menu $=4 \&$ menu $2=0 \& \mathrm{id}=$ 172 (Accessed 20.04.2018).

14. http://atlaspacket.vsegei.ru/\#023f61f2999916b05 (Accessed 21.04.2018).

15. S.L. Gorin, M.V. Koval, A.A. Sazonov, P.N. Tersky. Today's Hydrological Parameters of the Lower Reaches of the Penzhina River and First Data on the Hydrological Processes in its Estuary, as Obtained by the 2014 Expeditionary Force (Sovremenny gidrologichesky rezhim nizhnego techeniya reki Penzhiny i pervye svedeniya o gidrologicheskikh protsessakh v eyo eustarii (po rezultatam ekspeditsii 2014 g.)). / Research of Water Bioresources of Kamchatka and North-Western Pacific (Issledovaniya vodnykh biologicheskikh resursov Kamchatki i severo-zapadnoy chasti Tikhogo okeana. Issue 37, p. 35-52). (2015).

16. E .Bekirov, N. Fursenko, Ecological Characteristics of Wind and Solar Farms (Ekologicheskaya kharakteristika raboty solnechnykh i vetrovykh elektrostantsy) // MOTROL, Vol 15, Iss. 5, p.145-150 (2013). 